İnsanın yaşam biçimi ve kültürel birikimi içinde her zaman sembolik bir yeri olan mobilya, kullanılmaya başlandığı ilk günden beri pratik kullanım işlevine ek olarak bir iletişim nesnesidir. Mobilya tasarımında iletişim, biçim dilini meydana getiren öğelerle; gösterge ve sembollerle sağlanmaktadır.

Geçtiğimiz yüzyıl başında tasarımla iletişim işlevinin farkına varılmasıyla birlikte mobilya, mesajların ve ideolojilerin iletilmesinde bir araç olarak kullanılmaya başlanmış; bugün ise teknoloji alanındaki gelişmelerin etkisiyle geniş bir anlam içeriğine ve çeşitliliğine ulaşmıștır. Sanatçıla ve tasarımcılar günümüzde mobilya formunu düşünce, felsefe, söylem, fikir, duygu ileten bir araç olarak görebilmekte; aynı zamanda deneysel üretimlerin, çağdaş malzemelerin, bilimsel araştırmaların, güncel tasarım ve üretim yöntemlerinin denendiği bir uygulama alanı olarak da kullanabilmektedir. Tasarımları kendi birikimi, yaşam stili ve beğenileri doğrultusunda yorumlayan kullanıcı bu tür ürünleri kendisine farklılaşma duygusu verdiği, statü sağladığı ya da bakış açısını betimleyici nitelik taşıdığı için tercih edebilmektedir. Sembolleşen mobilya, kavramsal içeriğin ve mesajın pratik işlevden baskın olduğu, çağdaş sanatın ve tasarımın ortak paydasında yer alan boyutuyla öne çıkmaktadır.

\section{Abstract}

Since the commencement of its use furniture, which always stood on a symbolic ground through the lifestyles and cultural accumulations of the human beings, has always been an object of communication as well as its practical use. This communication is conveyed by means of units which constitute the medium of form, indicators and symbols. Upon the recognition of communication via design in the beginning of the last century, furniture has gained a use of transmitting messages and ideologies. Today, furniture has reached to a broad content and variety. Artists and designers look into the form of furniture as an instrument to convey ideas, philosophy, statements and emotions. And furniture has become an application area where experimental productions, contemporary materials, scientific researches, current designs and ideas take place at the same time. The end user who reads the desings from his/her perspective is free to pick one amongst which gives the feeling of differentiation and gaining status in the society or which has a descriptive way matching with the end user's point of view. Symbolized furniture comes forth in the common ground of contemporary art and design by having the conceptual content and message more dominant than the practical use.

Anahtar Kelimeler:

Biçim Dili, Sembol, İletişim, Mobilya Tasarımı, Sosyal Analiz, Teknolojik Boyut. Keywords:

Medium of Form, Symbol, Communication, Furniture Design, Social Analysis, Technical Extent.

\title{
Mobilyanın sembolleşmesi ve Güncel Yönelimler
}

Doktora Makalesi

Işıl ÖZÇAM, H. Şebnem UZUNARSLAN

Mimar Sinan Güzel Sanatlar Üniversitesi

Mimarlık Fakültesi, İç Mimarlık Bölümü

MSGSÜ, Fen Bilimleri Enstitüsü, İç Mimarlık Programında tamamlanmış "Biçim Dili ile İletişsim Ekseninde Mobilyanın Sembolleşmesi ve Günümüz Mobilyasınin Sembolleșmesinde Rol Oynayan Sosyolojik ve Teknolojik Etkenler" basslkkl tezden Kastm 2013 tarihinde olușurulan bir makaledir. Makale metni 10.11.2013 tarihiyle dergiye ulaşmış, 20.11.2013 tarihinde basım kararı alınmıştır. Makale ile ilgili tartışmalar 1.06.2014 tarihine kadar dergiye gönderilmelidir.

Bu makalede; mobilyada sembolleşme olgusu biçim dili ile iletişim ekseninde incelenmiş ve günümüz koşulları içerisinde değerlendirilmiştir. İlk olarak gösterge ve semboller yoluyla iletişim olgusu ele alınmış; tasarım-biçim ilişkisi detaylandırılmıştır. Mobilyanın izleyiciye/ kullanıcıya iletilmek isteneni vurgulayan bir araç niteliğinde kullanımıyla başlayan sembolleşme sürecine bağlı olarak gelişen tasarımlar örneklenmiş; ardından günümüzde mobilyanın sembolleşmesine etki eden faktörler sosyal ve teknolojik açılardan irdelenmiştir.

\section{Mobilya ile Illetişim İşlevi}

Mobilya, kullanım işlevine ek olarak bir bildirişim nesnesi, mesaj ileten bir araç ve anlam taşıyıcısıdır. Biçim dili ile çevresine, işlevine, yapım amacına, kullanıcısına ve tasarımcısına dair bilgiler ileten mobilyada iletişim, tasarımı meydana getiren gösterge ve sembollerin kullanıcıya/izleyiciye aktarılması ile sağlanmaktadır. Sembol veya simge, bir anlamı karşılayan işaretin genel kabul görerek toplumsal bir kod haline dönüşmesi olarak tanımlanabilir (Buchler 1955, 102). Semboller tasarımda anlam ve mesajların taşınması amacıyla bilinçli olarak tasarlanmakta ve kullanılmaktadır. Mobilyada 'gösterge' veya 'im' ürünün biçimi, rengi, malzemesi, kısacası bütünü oluşturan tüm özellikleridir. Belli faktörler nesnelerin belli göstergelerle biçimlenmesine sebep olduğundan, bunlara bakarak mobilyalar hakkında fikir sahibi olunabilir. Bu faktörler arasında stiller, dönemler, üretim şekli, tasarımcı, kullanıcı, toplum ve kurum kimlikleri gibi pek çok etken sayılabilir.

Ürün biçimi, sahip olduğu görüntüsel göstergesellik aracılığıyla kimi zaman belli nesne, kavram veya olgulara gönderme yapmaktadır. Benzerlik üzerine kurulmuş çağrışımlarla oluşturulan bu tür göndermeler 'eğretileme' ya da 'metafor' olarak adlandırılmaktadır (Bayrakçı 2004, 39). Tasarımcı, metaforda iletişim kaygısıyla biçimlere bilinçli anlam yüklemektedir. $\mathrm{Bu}$ benzetmeler gerçek nesnelere olabildiği gibi; kavram, düşünce, biçim, görüş, olgu, gelenek ve duygulara da 

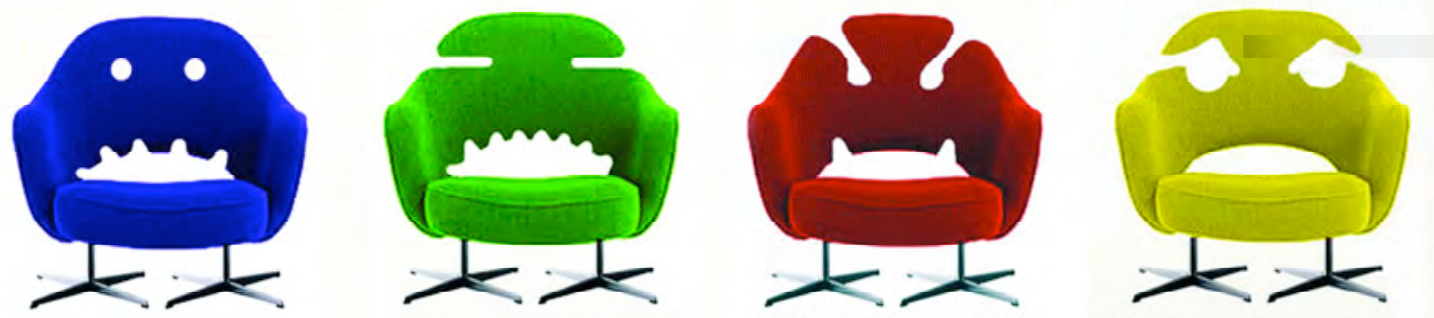

yapılabilmektedir. Sanatın bir çok dalında, özellikle nonfigüratif sanat yapıtlarında görülen; ama aynı zamanda tasarımı da doğrudan ilgilendiren metaforlar yoluyla kurulan benzerlikler çoğunlukla, nesne ile zihinsel kavramlar arasında uyaran bağlantılar akla getirmekte; bir varlığı, başka bir varlığa dayanarak görmeyi sağlamaktadır (Özsoy 2009, 5). Metaforlar, kimliklendirme ve yorumlama etkinliklerinde hem tasarımcı (gönderici), hem de kullanıcı (alıcl) tarafından sıklıkla kullanılmaktadır. Eğretilemenin sanat nesnesi tasarımındaki rolü bir mesaj veya felsefe iletmek iken; satış amaçlı tasarımdaki rolü ise iletilen bilgiyle nesneyi anlaşılabilir, ilginç, bilindik ve istenir kılmaktır. Resim 1'deki çizgisel anlatımlı yüz ifadelerine gönderme yapan oturma elemanları, mobilyada günümüz tasarım anlayışı içerisinde metafor kullanımına örnektir.

Metafor kullanımının 20.yy'da en bilinen örnekleri Alchimia ve Memphis grubu tasarımcilarına aittir. Bunlar tasarımda iletişim işlevini ilk olarak ifade etmiş ve 'Tasarım bir iletişim nesnesidir.' diyerek ürünlerini metaforik göndermelerle biçimlendirmişlerdir (Uzunarslan, 2010). Mobilya-sembol ilişkisinin, modernizmle birlikte tasarımın iletişim işlevinin tanımlanmasıyla bir değişim sürecine girdiği görülmektedir. Bu dönem öncesinde çağın getirdiği göstergelerle biçimlenen mobilyalar, modernizm sonrasında bilinçli olarak sembolleştirilmeye başlanmıştır. Gerrit Rietveld hem biçimsel, hem fonksiyonel anlamda De Stijl ideallerini ortaya koyan Resim: I f̧izgisel anlatımlı yüz ifadelerine gönderme yapan oturma elemanları. 'Red and Blue Chair' isimli mobilyasını 'Toplumda eşitlik, tasarımda dürüstlük' ilkelerinin bir bildirisi olarak üretmiştir. 1980'lerde deneysel çalışmalarla tasarım dünyasındaki kargaşaya bir çıkış yolu aramayı, tabulaşmış konuları irdelemeyi, o dönemde modernizmin dayandırıldığı bilimsel temellerin geçersizliğini kanıtlamayı ve felsefi açıdan yeni bakış açıları getirebilmeyi amaçlayan postmodernist tutum, tasarımı bir 'iletişim aracı' olarak tanımlamış ve mobilyaları bildiri nesnelerine dönüştürmüştür.

Günümüzde iletişim işlevi öne çıkan mobilyada sembol ve metaforların kimlik ve söylem tanımlayıcı birer biçim olarak sıklıkla kullanıldığı görülmektedir. Göstergeler ve metaforlar yoluyla mobilya, işlevsel ve/veya özelleşen sembollerle kimi zaman tasarımcısına; kimi zaman kullanıcısına ait bilgiler iletmektedir. Mobilyanın izleyiciye/ kullanıcıya iletilmek isteneni vurgulayan bir araç niteliğinde tasarlanması bu çalışma kapsamında 'mobilyanın sembolleşmesi’ olarak tanımlanmıştır.

\section{Mobilyanın Sembolleşmesi}

Sembolleştirme, somut veya soyut bir durum, kavram veya gerçeklik arasında algılanabilen bir bağ kurmak olarak tanımlanabilir.

Renk, form, malzeme, boyut gibi biçimsel 

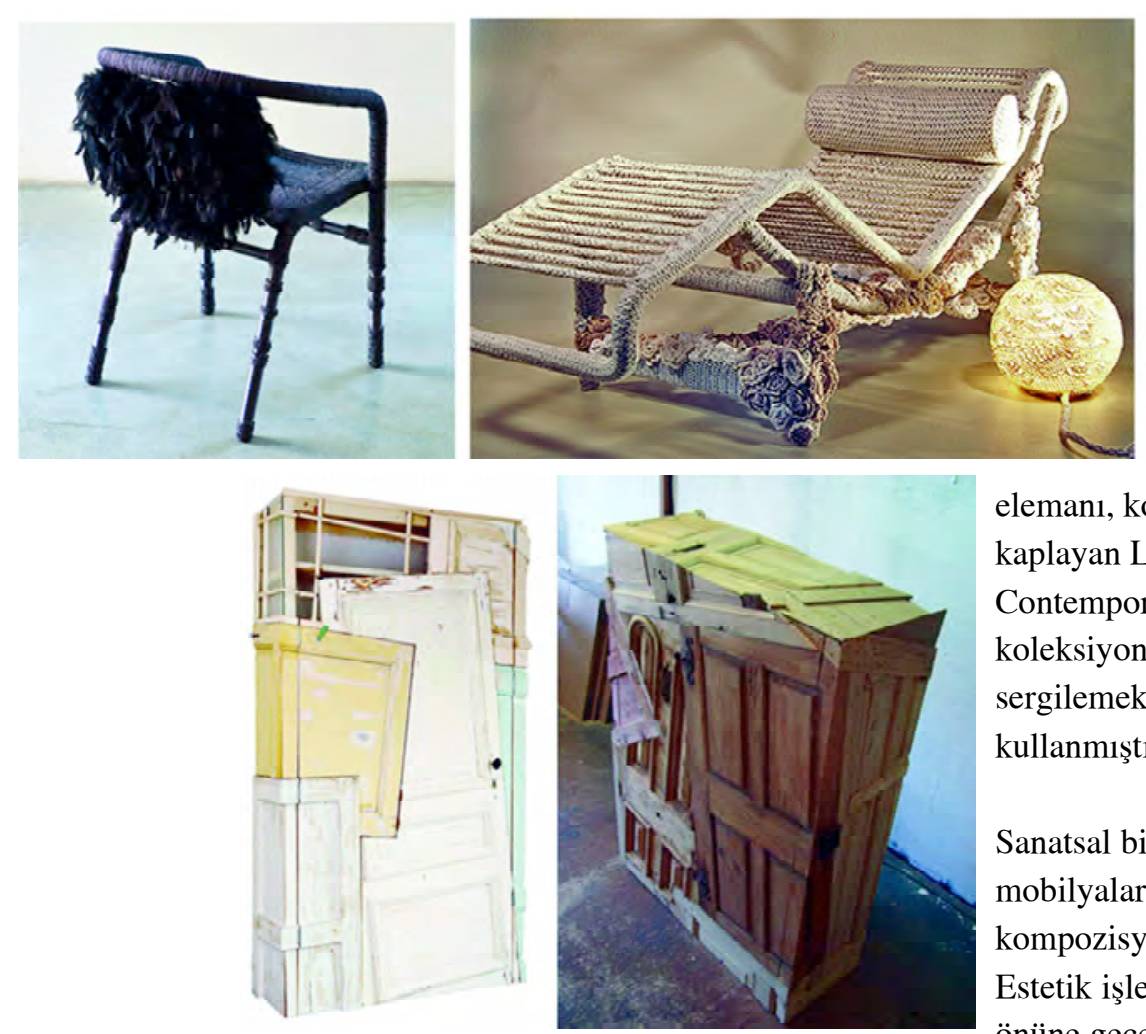

Resim: 2 Özellikleri programlanarak Loredana Bonora, 'Nodi sembolleştirilen mobilyalar, bu yolla Contemporanei', 2012. tasarımcının felsefi ve/veya estetik imler

Resim: 3 yüklediği, izleyicinin/kullanıcının ise Chris Ruhe, 'Only Doors', bilinçaltını harekete geçiren bildiri
2010. nesnelerine dönüşmektedir.

Sembolleşen mobilya genel anlamda -pratik kullanım işlevi olsun, ya da olmasın- bir sanat ve iletişim nesnesidir. Bugün pek çok tasarımcı mobilya formunu estetik görüş ve kavramsal mesaj iletmek amacıyla kullanmaktadır. $\mathrm{Bu}$ noktada nesnenin hangi mantık ve estetik değerlere göre tasarlandığı önem taşımaktadır. Kimi zaman nesneler çok yönlü alt anlamlara ve özelliklere sahip olabilmektedirler. El işçiliği ile yapılmış tasarımlar ve heykelsi mobilyalar, üzerinde estetik yüklemeler yapılarak biçimlendirilen tasarımlara örnektir. Plastik ve koton bazlı malzemelerle ördüğü tığ işi örtülerle masa, aydınlatma

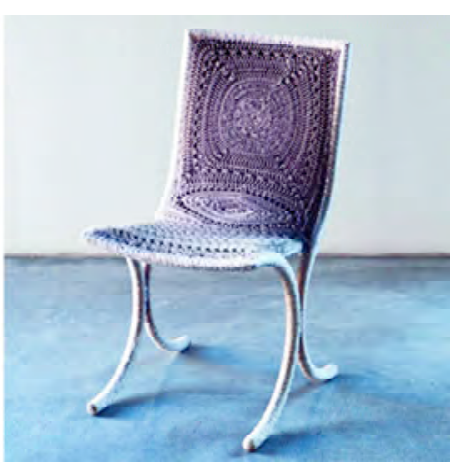

elemanı, koltuk gibi nesnelerin yüzeylerini kaplayan Loredana Bonora, 'Nodi Contemporanei' adını verdiği koleksiyonunda mobilyayı kendi sanatını sergilemek için bir araç olarak kullanmıştır (Resim 2).

Sanatsal bildiri niteliğindeki sembol mobilyalarda biçimsel denge ve görsel kompozisyon ilkeleri önem taşımaktadır. Estetik işlevi, pratik ve sembolik işlevinin önüne geçen mobilyalara örnek olarak Hollandalı tasarımcı Chris Ruhe'nin 'Only Doors' projesi kapsamında ürettiği dolap tasarımları gösterilebilir. Kullanılmış antika kapıların bir araya getirilmesiyle oluşturulan, ince detay ve işçilik içeren tasarımlarda bazı menteşe ve kulplar fonksiyonel olmadı $\breve{g} 1$ halde estetik kullanım için özellikle bırakılmıştır (Resim 3).

Bireysel üretimlerinin yanı sıra tasarımcılar, kimi zaman mekana veya kişiye özel sanatsal mobilyalar üretebilmekte; metaforik tasarımlar yapabilmektedir. Bu durumda ortaya çıkan nesnenin estetiği mekan bütünlüğüne katkı sağlayacak biçimde şekillenmektedir.

Belirli bir mekan için üretilmiş sembol mobilyalara örnek olan 'Out of the Strong Came Forth Sweetness', Ian McChesney tarafından Londra'daki Angel Binası avlusu için tasarlanan 22 metre yüksekliğinde bir oturma elemanıdır. Tasarımcının ters duran bir kaşıktan 


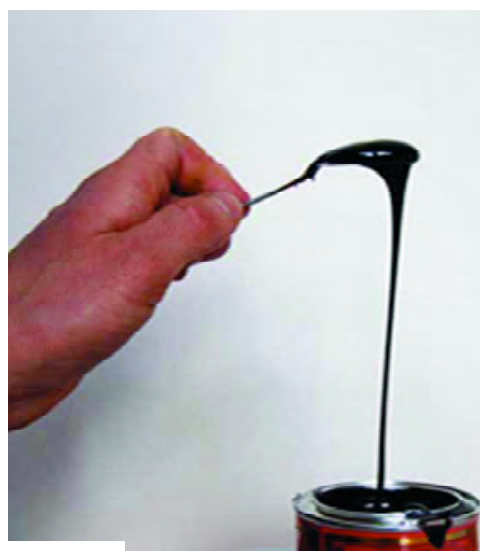

Resim 4

uzayan şeker şurubu formundan esinlenerek tasarladığı heykelsi oturma elemanı, hafif ve güçlü bir malzeme olan karbon fiberden yapılmıştır (Resim 4).

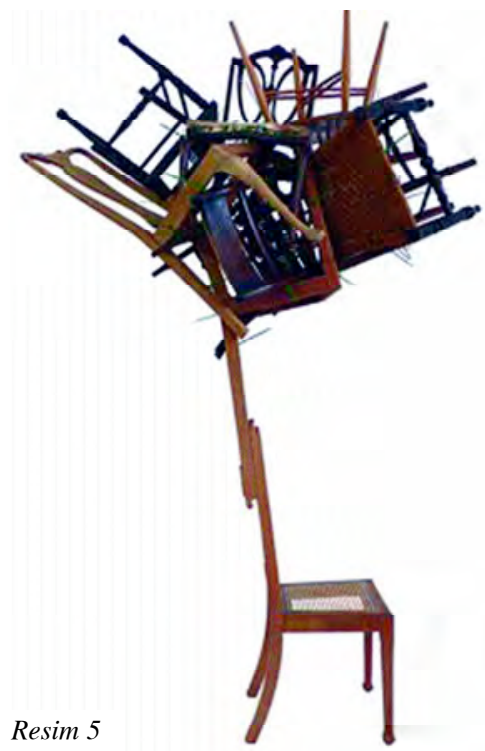

Sanatçılar ve tasarımcılar, günümüzde giderek gelişen çağdaş sanat piyasasının da etkisiyle sosyal, ekonomik, siyasi veya psikolojik hemen her konuda fikirlerini iletmek için mobilya formunu kullanabilmektedir. Buna göre, verilmek istenen mesajlar mobilya üzerine semboller ve metaforlar yoluyla yansitılmakta; tasarımlar bu yolla felsefe kurgusu ileten düşün ürünleri olarak programlanmaktadır. Karen Ryan, 'In The Woods Chair' adlı çalışmasını, yaşadı ̆̆ı yerden topladığı sandalyeleri ağaç formunda bir araya getirerek

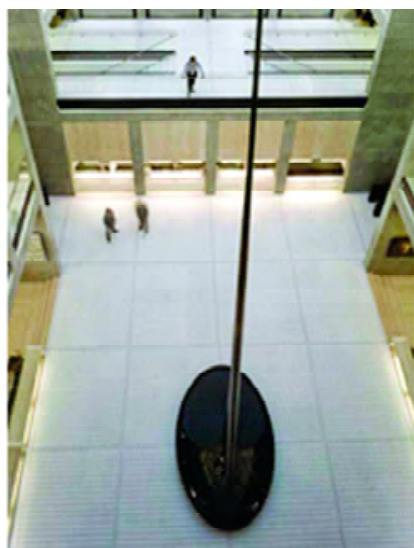

oluşturmuştur. Ryan, kullandığı ağaç metaforu ile çevre kirliliğine atıfta bulunmuştur (Resim 5).

Sembolik işlev taşıyan, felsefi sembollerle yüklü nesneleri izleyicinin/kullanıcının anlamlandırabilmesi ancak belli birikimlerle mümkündür; aksi halde biçimler izleyiciye bir şey ifade etmemekte ya da farklı çağrışımlara neden olarak amacının dışında yorumlara ulaşmaktadır. Ancak, algılanan anlamların karşılığı kullanıcıda bulunuyorsa mesaj iletimi gerçekleşmektedir. Örneğin, John Angelo Benson'ın 'Mies Lobby Trap' adlı eserini modernizmin bir eleştirisi olarak görebilmek, ancak bu tasarımın orijinalini bilmekle mümkündür. Mobilya formunda kavramsal bir çalışma niteliğindeki tasarım, Mies van der Rohe'nin 'Barcelona Koltuğu'na (1929) paslanmaz çelikten kabaralar (çiviler) eklenerek ve işlevi yok edilerek gerçekleştirilmiştir. Böylece alıcıya, alışılmadık içerikle yeni bilgi verilmekte, farklı bir uyarı yapılmaktadır. Bu durum, izleyiciyi neden böyle bir çaba içine girildiğine dair düşündürmektedir. Pratik işlevi yok edilen koltuk, modernizmi sorgulayan felsefi bir nesneye dönüştürülmüştür (Resim 6).

Çağdaş sanat çevrelerine bakıldığında son yıllarda mobilya tasarımı ve sanat arasındaki sınırların kaybolmaya başladı̆̆ı;
Resim: 4

Ian McChesney, 'Out of the Strong Came Forth sweetness', 2011.

Resim: 5 Karen Ryan, 'In The Woods Chair', 2009. Resim: 6 John Angelo Benson, 'Mies Lobby Trap', 2003. 
mobilya tasarımlarının galerilerde, sanat fuarlarında, müzelerde, açık arttırmalarda sergilendiği ve satıldığı görülmektedir. Tasarım-sanat arası çalışmaları 'Design Art' olarak tanımlayan Alexander Payne, 1999 yılında bu tanımı ilk ortaya attığında tasarım ve sanat arasındaki sınırların belirsizleştiğine, girişim halinde olduğuna ve ortak bir dilde birleştiğine dikkat çekmek istemiştir (Lovell 2009, 111). Sembolleşen mobilya tasarımları, günümüzde giderek daha çok tasarımcının / sanatçının kendini ifade etme aracı olmakta ve sıklıkla karşımıza çıkmaktadır.

\section{Günümüz Mobilyasının}

Sembolleşmesinde Rol Oynayan Sosyo-Kültürel Etkenler

Küreselleşme olgusunu hızla hayatımıza aktaran 21. yy. iletişim ortamı, bireysel gereksinimlerin de değişmesine sebep olmuştur. Günümüzde kimlik özelliklerini ifade aracı olarak da dolaylı bir işlev kazanan sembol mobilyaların biçimlenişinde sosyo-kültürel etkenler yönlendirici olmaktadır.

\subsection{Tasarımcı Yönelimleri}

Günümüzde tasarımcıların tesadüfi veya özellikle seçilmiş sembollerle mobilya tasarımlarını biçimlendirmeleri, bu süreçte hemen her şeyi tasarımlarının konusu olarak kullanabilmeleri, içinde bulunduğumuz değişim ve etkileşim halindeki sosyo-kültürel ortamın bir sonucudur. Küreselleşmenin aynılaştırdığı toplumsal düzende kültürler arasındaki farklılıklar giderek tasarımın konusuna dönüşmektedir. Evrenselleşen bir düzlemde toplum ve bireyler arasındaki bu etkileşimler, tasarımcıların ortak yönelimler geliştirmesine; kullanıcıların ise bu mobilyaları benzer gereksinimler nedeniyle tercih etmesine neden olmaktadır.

Farklı kültürel geçmişe, kimliğe ve hayat görüşüne sahip tasarımcılar mobilyalarında özgün imler kullanmakta; ancak bunu yaparken benzer yönelimlerle hareket etmektedirler. Mobilyayı bir sembol olarak gören tasarımcılar, bu formu estetik görüş, inanç, ideoloji ve felsefelerinin ifadesi yapabilmektedirler. Tasarımcı kendi kimliğini, çizgisini veya düşünce tarzını yansıtırken değişik disiplinlerden etkilenebilmekte; eski stillerden, kültürel değerlerden, geleneklerden, çağrışım yolu ile sembolik benzetmelerden yararlanabilmekte, metaforlar kullanabilmekte, kullanıcı davranışlarından yola çıkabilmekte, bir stil izleyip onun üyesi olabilmekte, inancı ya da kimliği doğrultusunda bağımsız bir çizgi yaratabilmekte veya yeni tasarım ve üretim yöntemleri geliştirebilmektedir. Kimi zaman tasarımcı kimliğini ortaya koyan, kimi zaman kullanıcı tercihlerine yönelik tasarlanan sembol mobilyalar, satış ve sergileme önceliklerine göre nitelik değiştirmektedir.

Özel ve sayılı üretim mobilyalar, seri üretime uygun olma zorunluluğu taşımayan; tasarımcının daha özgür olabildiği, kendi programını oluşturabildiği, satış ve pratik işlev kaygısı olmadan biçimlendirebildiği tasarımlardır. $\mathrm{Bu}$ nesneler genellikle tasarımciların bireysel çabaları, firma ve galerilerle işbirlikleri sonucu ortaya çıkmaktadır. Seri üretim mobilyalar ise çeşitli firmalar tarafından geniş kitleler için endüstriyel olarak üretilmektedir. Satış öncelikli üretilen bu tasarımlarda kullanıcı faktörü de devreye girmektedir; bu durumda tasarımcı, firmanın belirlediği ve kendisinden talep edilen program 


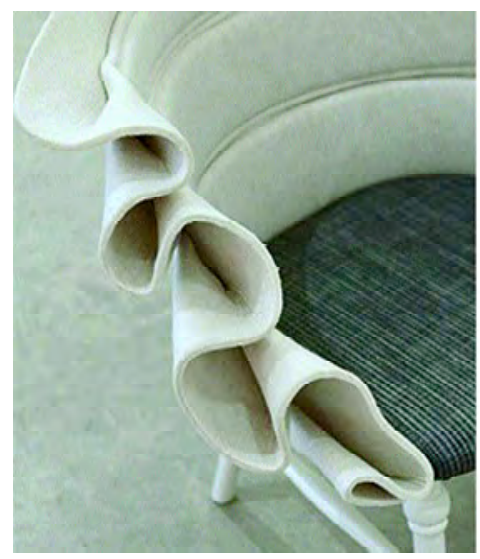

doğrultusunda hareket etmektedir. Her iki şekilde de tasarımcıların kimlik belirleyici olarak veya dikkat çekmek için belli sembollere yöneldiği, mobilyada biçim dilini farklı anlamların göstergesi olan imlerle programladığı görülmektedir. Tasarımcıların duyum, algı, gözlem, düşünme ve hayal gücü gibi yetileri tasarım programı oluşturma ve nesnel bir bütüne ulaşma noktasında önem kazanmaktadır.

Bir konudan esinlenme/metaforik gönderme yapma noktasında tasarımcılar farklı bilim, sanat ve çalışma alanlardaki form, detay ve üretim yöntemlerini mobilya tasarımlarında

kullanabilmektedir. Moda, jeoloji, biyoloji gibi pek çok farklı disiplin günümüz tasarımlarına bu anlamda ilham verici olmaktadır. Mobilyalarını klasik giysi tasarımları ile ilişkilendirerek metaforik göndermeler yapan Fredrik Färg, kalıplanabilir polyester keçe kullandığ mobilya arkalıklarını moda ve tekstil tasarımı alanında kullanılan klasik dikiş teknikleri ile biçimlendirmektedir (Resim 7).

Tuval bezine basılı bir koltuk fotoğrafından oluşan 'Canvas Chair', duvara dayandığında bir oturma elemanı
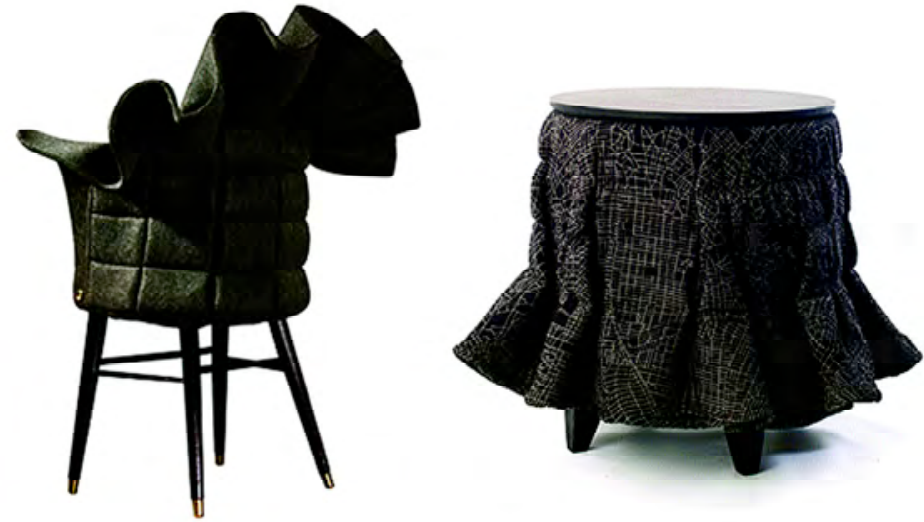

olarak işlev görmektedir.

Ahşap/alüminyum bir çerçeve etrafına

Resim: 7

Fredrik Färg tasarımları. gerilen elastik kumaştan oluşan mobilyanın tek ve iki kişilik versiyonları vardır. YOY Design tasarımı mobilyada resim ve grafik sanatının etkileri görülmektedir (Resim 8).

Tarihsel süreçte yer almış formlar günümüz mobilyalarında tasarımcılar tarafından kullanılabilmekte; çağdaş
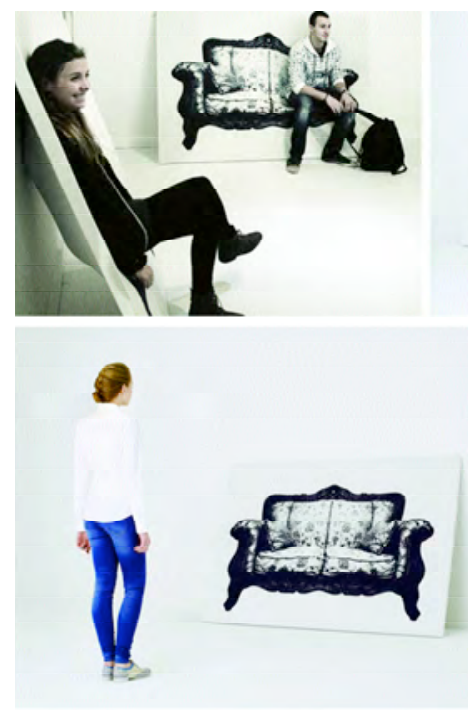

malzemelerle, farklı biçim düzenlemeleri ile yorumlanarak sembolleştirilebilmektedir.

Değişik dönem ve stillerden seçtiği mobilya parçalarını birleştirerek yaptığı biçim denemeleri ile Borek Sipek, çoğu 

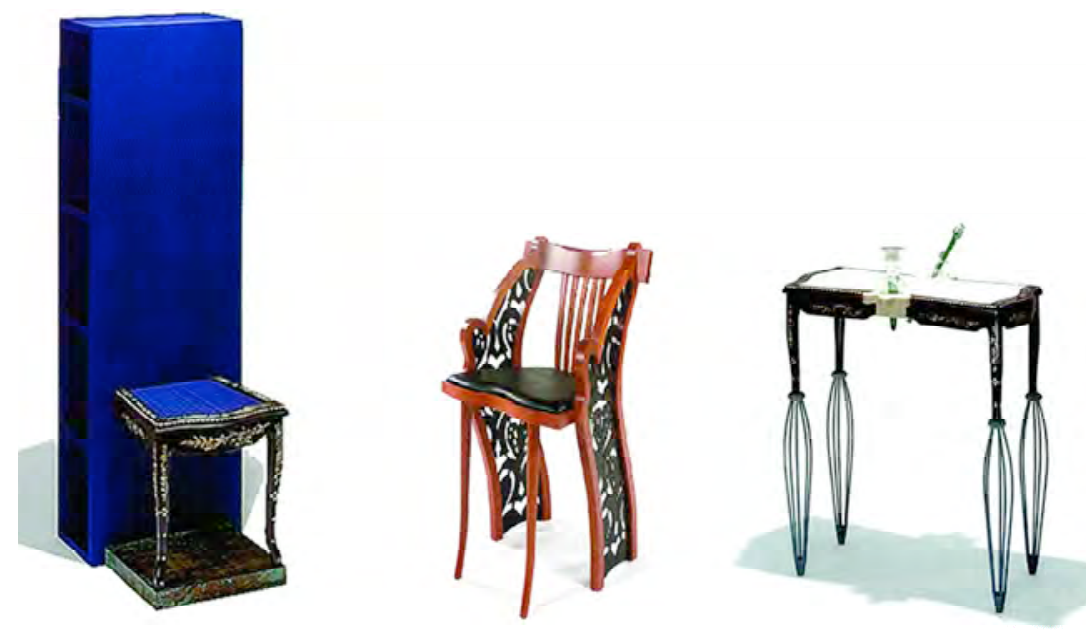

Resim: 9 zaman geleneksel ve güncel semboller Borek Sipek tasarımları.

Resim: 10 Marcel Wanders, 'Crochet Table', 2001 ve 'Crochet Chair', 2006 getirerek postmodern bir düzlemde tanımlamaktadır (Resim 9).

Etnik, kültürel ve geleneksel sembollerin mobilyalar üzerinde kullanımı biçimsel boyutta olabildiği gibi, malzeme ve üretim
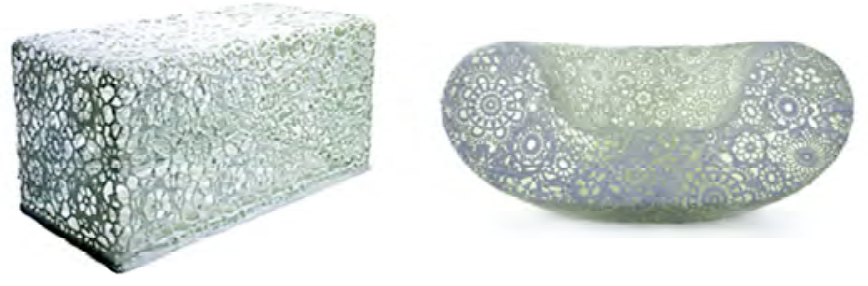

Resim 10

Resim: II Farklı kimliklere yönelik tasarlanmıs mobilyalar. tercihi olabilmektedir. Geleneksel sembollerden yola çıkarak mobilyalarını biçimlendiren tasarımcılardan Marcel Wanders'in dantel işinden yola çıkarak tasarladı ̆̆ 1 'Crochet Chair' ve 'Crochet Table', tığla örülmüss dantel örtülerin dikilmesi, epoksi reçine ile sertleştirilmesi ve kalıpla biçimlendirilmesi ile meydana getirilmiştir (Resim 10).

Mobilyanın sembolleşmesinde rol oynayan bir faktör de satış noktasında ortaya çıkan kullanıcı beğenileridir. Tasarımcı kimi zaman belirli bir kesimin yaşam biçimini, sosyal yapısını ve estetik beğenisini göz önüne alarak tasarım yapmaktadır. Bu noktada kullanıcı tercihleri tasarım bileşeni olarak tasarım sürecine dahil olmaktadır. Estetik beğeni herkese göre değişken olsa da kullanıcıya ait bazı imler bellidir. Sosyo-kültür, statü, yaş, cinsiyet, etnik kimlik gibi değerler dikkate alınarak tasarımcı tarafından belirlenen semboller mobilyalar üzerinde ürünün estetik işlevine katkıda bulunacak şekilde programlanmaktadır; mobilyalar bu yolla kullanıcısını ve mekanını tanımlayan bildiri elemanlarına dönüşmektedir (Resim 11).

Sembolik mobilya tasarlama sürecinde işlevsel açıdan farklı tasarım tanımlarına ulaşmak isteyen tasarımcı için kullanıcı etkileşim ve davranışları, önemli bir çıkış noktasıdır.

Her davranışın belli bir nedene dayandığını bilen tasarımcı, kullanıcının ihtiyaçlarına nasıl cevap vereceğini de
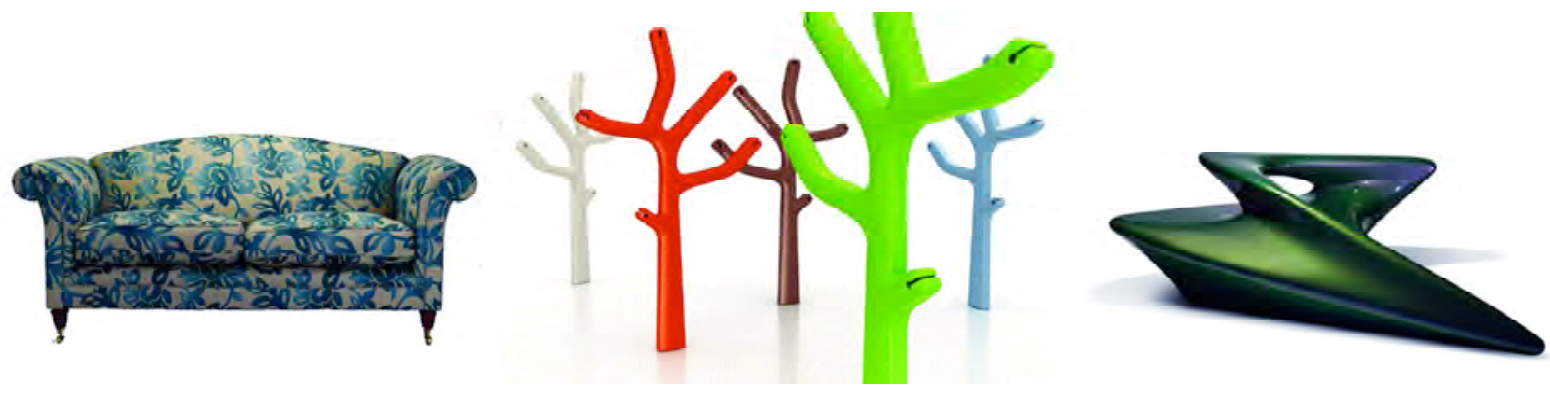
öngörebilir; buna yönelik olarak tasarımını programlayabilir (Zapçı 1996, 61). Ancak bazen bunun tam tersi de geçerlidir; tasarımcı aynı zamanda ihtiyaç, davranış ve alışkanlıkları biçimlendirebilen kişidir. Getirdiği tanımlarla toplumu şekillendirebilir; insan-çevre ilişkilerini düzenleyebilir, işlevsel açıdan farklı tanımlar yaparak yeni kullanım yöntemleri oluşturabilir ve kullanıcıya yeni deneyimler kazandırmayı amaçlayabilir. Bireysel veya toplumsal davranış ve alışkanlıklar göz önüne alınarak yapılan işlevsel tanım ve programlar, yeni kullanım biçimlerinin geliştirilmesine de yardımcı olmaktadır. Nani Marquina'nın insanların evde ve kamusal alanlarda yere

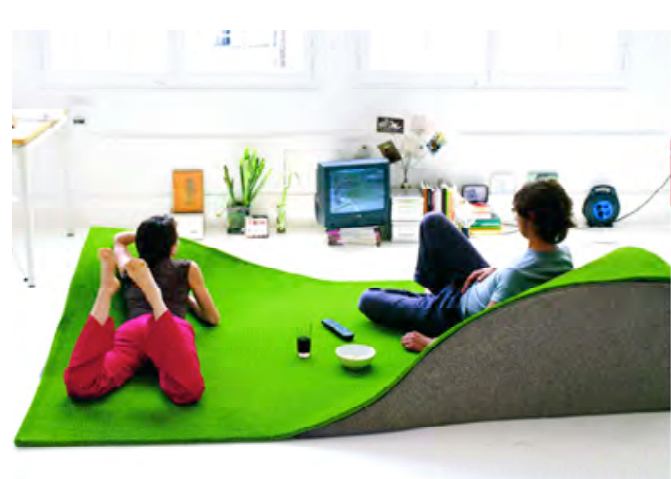

Resim 12

oturma alışkanlığından esinlenerek tasarladığı bir düzlem olan 'Flying Carpet', işlevsel açıdan yeni kullanım biçimleri sunarak özgürlüğü sembolize etmektedir (Resim 12).

\subsection{Kullanicu Tercihleri ve Gereksinimleri}

Günümüzde sembolik mobilyaların tercih edilme noktasında kullanıcı gereksinimleri öne çıkmakta; her birey kendi özellikleri (kimlik, kişilik, hayat tarzı, inanç, dünya görüşü, ihtiyaçlar ve özlemler) doğrultusunda mobilyalar beğenmekte, satın almakta ve kullanmaktadır. Bireylerin mobilyalara yükledikleri simgesel anlamlar, tercih nedenleri ve beklentileri, kişisel ve toplumsal bazda oluşturdukları kavramlaştırmalara dayalı olarak değişmekte, bu ise kimlik olgusunun kültürel özelliğini ortaya koymaktadır.

Kullanıcı tercihleri incelendiğinde öne çıkan yönelimlerden birinin kişiye özel biçimlenme olanağı sunan mobilyalar olduğu görülmektedir. Kişiselliğin önem kazandığı günümüzde mobilya işlevleri de özgün formlar içerisinde aranmaktadır. Esnek ve yaratıcı çözümlerle kullanıcının istediği gibi programlayabildiği, farklı malzeme ve renk imkanları sunan tasarımlar için Ron Arad, 'Kişide ürünü kendi biçimlendiriyor illüzyonu yaratarak,
Resim: 12

Nani Marquina,'

Flying Carpet', 2006.

Resim: 13

yoy Design, 'Blow', 2012.
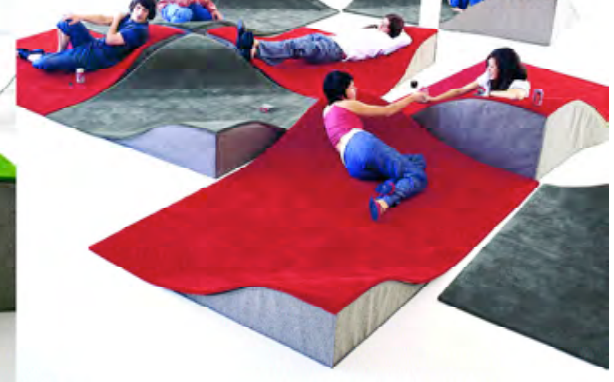

tasarımın bir boyutunda rol aldığ 1 hissini yaşatıyor' yorumunu yapmıştır (Arad, 2013).

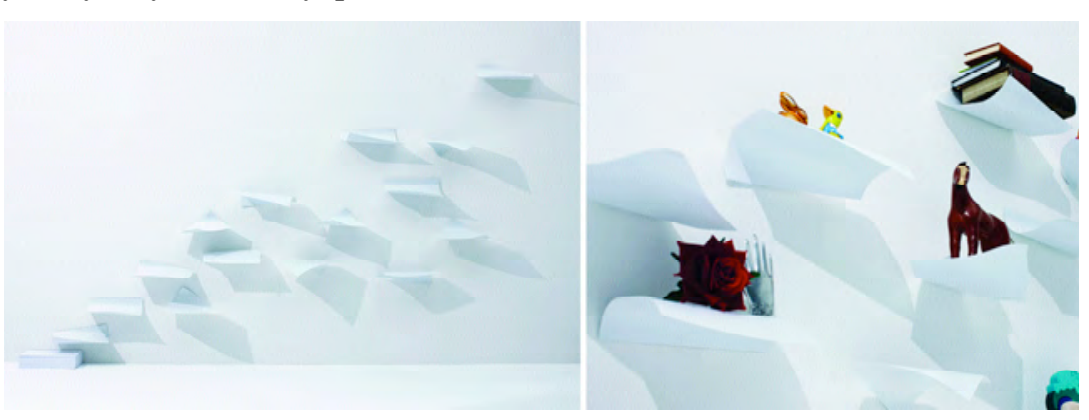

Resim 13

Bunun bir örneği olan 'Blow', A4

boyutunda ince çelik plakaların beş ayrı formda kalıplanarak biçimlendirilmesiyle oluşturulmuş bir raf ünitesidir. Uçuşan bir kağıt destesini andıran tasarım, 


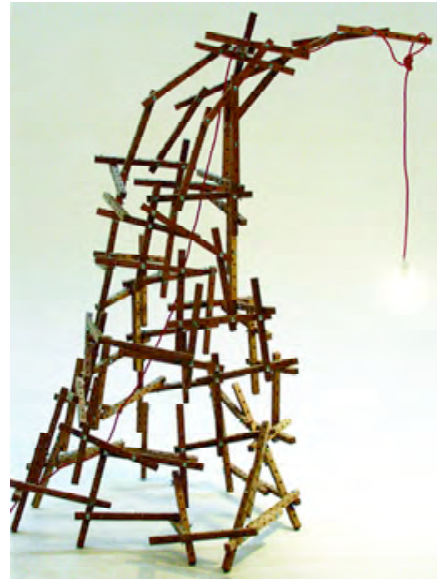

Resim: 14

David Grass, 'Everything But The Manual', 2011.
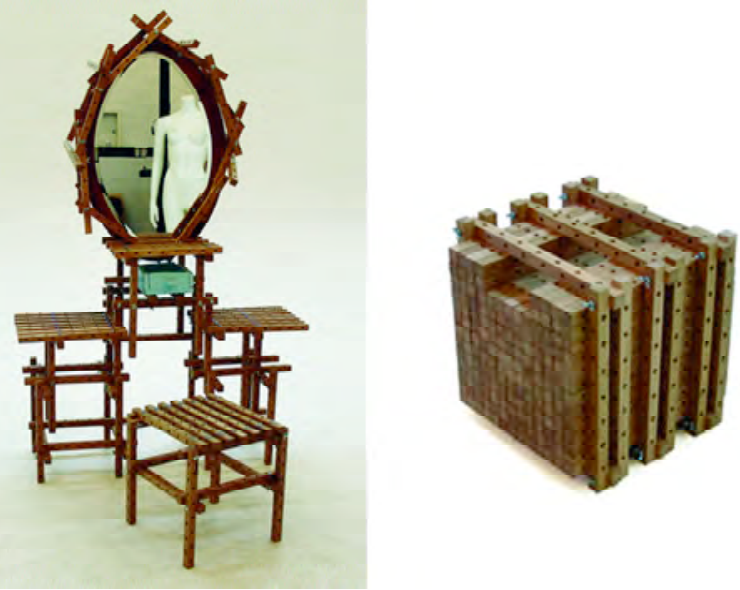

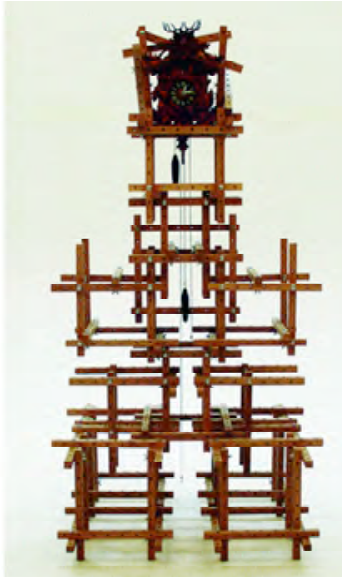

duvara çengellerle monte edilebilmekte; kullanıcı parçaları istediği gibi düzenleyebilmektedir (Resim 13).

Kullanıcılar, tasarım sürecine direkt ya da dolaylı olarak katılarak kendilerini ifade etmek istemekte; Kendin Üret (Do It Yourself) mobilyalar bu noktada tercih sebebi olmaktadır. Yüz yetmiş yedi adet ahşap parçadan oluşan 'Everything But The Manual', kullanıcının cıvata ve somunlar kullanarak özgürce biçimlendirebildiği modüler bir sistemdir. 'Form esnekliği izler' prensibi ile David Grass oyun niteliğindeki bu tasarımını, el işçiliğini seven kullanıcılar için üretmiştir. Mobilyalar, modüllerle birlikte verilen k1lavuz önderliğinde veya tamamen özgün formlarda biçimlendirilebilmektedir (Resim 14).

Resim: Is Alternatif kullanım biçimleri sunan Florence Jaffrain, mobilyalar, işlevsel veya estetik anlamda 'Wave sitting Spheres', 2011 . alışılmışın dışında bir deneyim kazanmak isteyen bireylere hitap etmektedir. Mobilyaların farklı işlevlerde ve formlarda üretilmesi 1960'ların özgürleşme hareketleri içerisinde başlamıştır. $\mathrm{O}$ dönemde 'kalıpların dışına çıkma' düşüncesiyle şekillendirilen ve bir ideolojiyi yansıtan tasarımların günümüz örneklerine bakıldığında, bunların orijinal olanı arama noktasında giderek daha çok kişinin tercihi olduğu görülmektedir. Nesne ile iletişimde önemli olan, kullanıcı ya da izleyicinin bu deneyimi yaşıyor olmasıdır. Günümüzde özellikle gençler hareketli yaşam biçimleri içinde bu tür mobilyaları daha çok tercih etse de, deneysel mobilyalar her yaştan kullanıcının ilgisini çekebilmektedir. Bir fille içerisine yerleştirilmiş toplardan oluşan 'Wave Sitting Spheres', oturma/uzanma eylemini yeniden tanımlayan ve her yaştan kullanıcıya hitap eden tasarımlara örnektir (Resim 15).

Sembolik mobilyaların kullanıcılar tarafından tercih edilme nedenlerinden biri de estetik tercihlerdir.

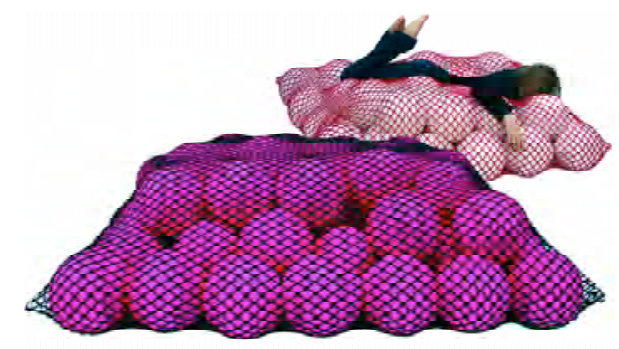

Resim 15

Kullanıcı beğenileri, kişilerin sosyal, etnik-kültürel, ekonomik ve teknolojik altyapısına, deneyimlerine, inançlarına, alışkanlıklarına ve estetik değer yargılarına bağlı olarak değişmektedir. Estetik değer, tasarımı eş işlevli benzerlerinden 
ayırmakta; bu farklılaşma nesnenin kullanıcı açısından beğenilmesinde ve tercih edilmesinde önemli rol oynamaktadır (Muggevd. 2008, 326). Estetiğin sembolik biçimle birleştiği bir tasarım olan 'Illusion Table', Essey firması tarafından 3 milimetre kalınlığında akrilik malzeme kullanılarak el işçiliği ile üretilmiştir (Resim 16).

Tasarımcıların bir felsefe ya da görüş bildirmek amacıyla ürettiği sembol mobilyalar kimi zaman bireyler tarafından -pratik kullanım değeri olsun ya da olmasın- sanatsal değeri için tercih edilebilmektedirler. Geçmişte ideoloji

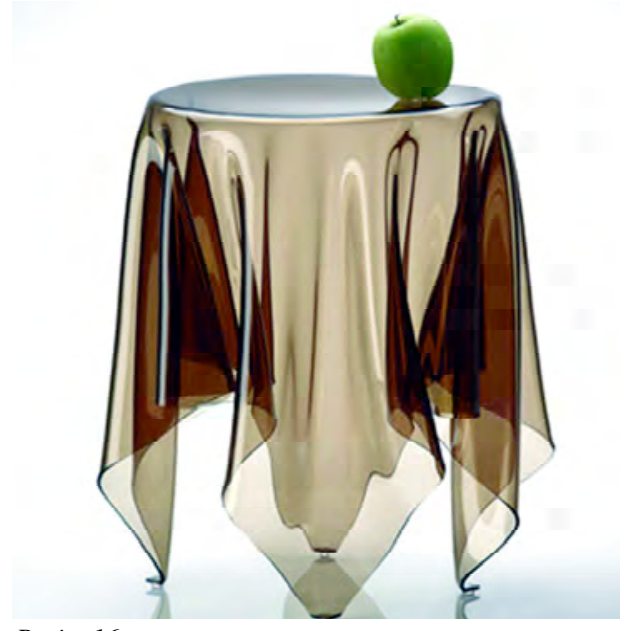

Resim 16

sembolü olan tasarımları günümüzde halen üreten firmalar mevcuttur ya da bu tasarımların orijinalleri bazı galerilerin koleksiyonlarında özel parçalar olarak yer alabilmektedir. Memphis grubu tasarımlarının satıldı $\breve{g}_{1}$ galeriler, firmalar ve açık arttırma şirketleri konuya örnek gösterilebilir (Resim 17).

Kişilerin refah düzeyi yükseldikçe psikolojik ihtiyaçları da çeşitlenmekte; insanlar konfor, statü, estetik, sanat gibi pek çok farklı nedenle mobilya alabilmektedir. Araştırmalar, tüketim öncelikli toplumlarda eşyaların kullanım değerinden çok sembolik değerleri dolayısıyla alındığını ve kullanıldığını göstermektedir (Bilgin 1983, 56). Bu, ürünlere yüklenen işlev ve sembollerin gruplara göre farklılaştığının bir göstergesidir. Yönelinen statü nesnelerinin seçiminde, kişilerin kültür düzeyleri, yaşam stilleri ve beğenileri de önemli rol oynamaktadır. Örneğin az sayıda piyasaya sürülen özgün mobilyalar, yüksek fiyatı nedeniyle herkesin alamadı ̆̆ı; buna paralel olarak kişilere farklılaşma duygusu veren, statü sağlayan ya da bakış açılarını betimleyici nitelik taşıyan ürünler olarak önemli yer tutmaktadır. Son dönemde lüks tüketime yönelik pek çok firmanın da pazara hakim olmak için sembolik mobilya üretimine öncelik verdiği görülmektedir. Bu tür mobilyaların düzenlenen sergi, medya, fuar ve açık arttırmalarda giderek daha çok ilgi çekmesi piyasayı harekete geçirmekte, bu ürünler özel bir pazar yaratmaktadir.

\subsection{Güncel Yönelimler}

Sosyal çevreye ve yaşam koşullarına bağlı olarak oluşan dönemsel yönelimler, tasarım yaklaşımları ve kullanıcı tercihleri üzerinde etki etmektedir.

\section{Güncel mobilyalar incelendiğinde tasarım Resim: 16} yönelimlerinin 'ekoloji, esneklik ve teknoloji' konuları üzerinde yoğunlaştığ görülmektedir. Popüler kültür imgelerini tasarımlara yerleşme çabası sonucu John Brauer, 'Illusion Table', 2005.

Resim: 17

Ettore Sottsass, Memphis tasarımları. biçimsel bir deformasyon da söz konusudur.
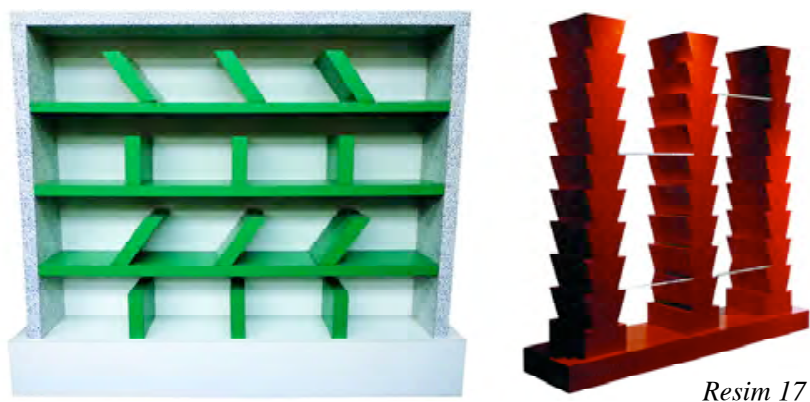

Resim 17 
Resim: 18
Studio Maezm, 'Re_Love',

2009.

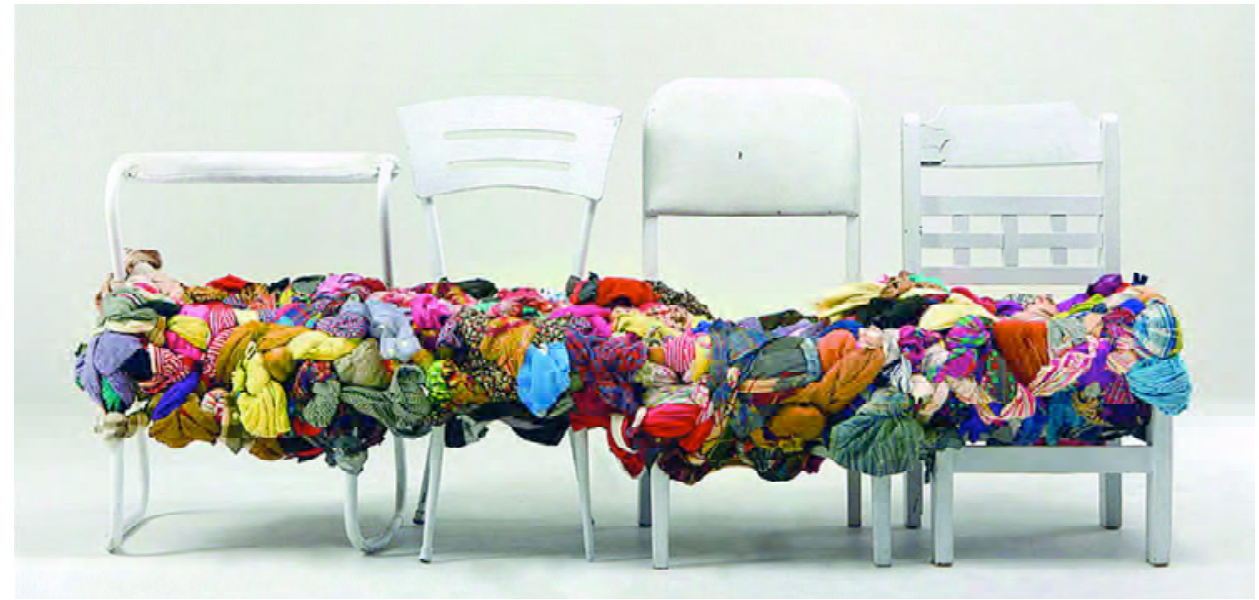

Artan çevre kirliliğine karşı oluşan bilinçlenme, sürdürülebilir/yeşil tasarımların artmasına neden olmakta; atık malzemeler tekrar kullanılmakta veya yeniden değerlendirilmektedir. Günümüzde sürdürülebilir ve atık malzemeleri mobilyalarında kullanan pek çok tasarımcı/firma bulunmaktadır. Sosyal mesajlar da veren bu sembolik tasarımlarda atık eşyalar, bilgisayar parçaları, araba lastikleri, eski giysiler vb. ya da ekolojik malzemeler kullanılabilmektedir. Kullanılmış giysi ve sandalyelerden oluşan 'Re_Love' ömrünü tamamlamış eşyaların yeniden

kullanılabileceğini göstermek için üretilmiş bir mobilyadır. Tasarıma ismini veren 'Re_Love' sözcüğü, burada 'yeniden kullanmak' anlamını taşımaktadır. Bu mobilya ile sürdürülebilir tasarım anlayışını ortaya koyan Studio Maezm, aslında eşya-insan arasındaki ilişkileri sorgulamaktadır; giysilerin insan hayatının özel anlarını ve hatıraları taşıyan önemli nesneler olduğunu ve eskidiğinde hemen atılmaması gerektiğini; bir şekilde

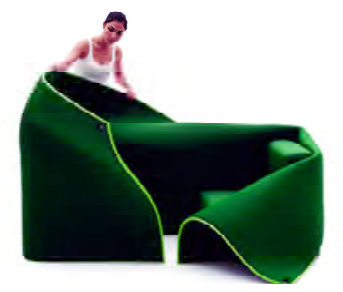

yeniden kullanılabileceğini vurgulamaktadır (Resim: 18).

Sembolleşen mobilyada bir diğer güncel yönelimin, yaşam mekanlarındaki küçülmeye ve dinamik/değişken yaşam tarzına bağlı olarak gelişen, az eşyayı özgürlük olarak kabul eden felsefe ile de bağlantılı olarak 'çok fonksiyonluluk' özelliğini kullanmak olduğu görülmektedir. Bu süreçte çağdaş malzemelerden ve üretim teknolojilerinden de yararlanan tasarımcılar, birden çok işleve cevap veren mobilyalarını kullanıcının tercihine sunmaktadır. Yatağa dönüşebilen ve pek çok farklı kompozisyonda kullanılabilen 'Sosia Sofa', Emanuele Magini tarafından üretilmiştir (Resim: 19).

Günümüzde oldukça sık rastlanan bir yönelim de mobilyaların popüler sembollerle, satış odaklı biçimlendirilmesidir. Firmaların daha çok kişinin dikkatini çekmek istemesi, bu tür yaklaşımların temelini oluşturmaktadır. Moda olan ve sosyal ortamda bulunan
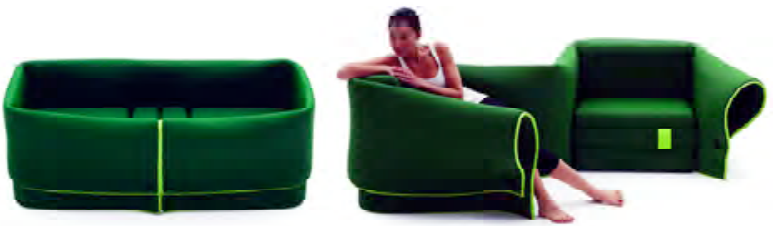
imgeler metafor olarak mobilyalar üzerinde kullanılmakta, tasarımlar bu yolla esprili bulunan, kolay sevilen nesneler haline getirilmektedir.

Tasarımda satışa yönelik politikalar sonucu her olgu bir tüketim nesnesine dönüşebilmekte; sanatçllar, sinema yıldızları, popüler kimlikler, karikatürler, medya/film karakterleri, yüz ifadeleri, bilgisayar işaretleri, inançlar, moda, sosyal aktiviteler, futbol takımları gibi günlük hayata ilişkin her şey tasarımlar üzerinde sembolleştirilebilmektedir. 1980'lerde öne çıkan ve 'Her şey olur' prensibiyle şekillenen postmodernizm anlayışı aslında günümüzde de geçerliliğini sürdürmektedir. Uzak Doğu kültürüne ait bir sembol olan Buda imgesinin oturma elemanı olarak kullanılması bunun bir örneğidir (Resim 20).

\section{1. yy. ekonomisi kendini ayakta} tutabilmek için yeni pazarlar aramakta ve yeni politikalar üretmekte, bunu takip eden kitleler de giderek daha fazla tüketim ve değişim odaklı yaşamaktadır. Moda, markalar, reklamlar, sloganlar, kimlik çalışmaları, akılda kalma ve satışa yönelik farklılık arayışlarının tamamı söz konusu tüketimi teşvik etmeye yöneliktir.

\section{Günümüz Mobilyasının}

\section{Sembolleşmesinde Rol Oynayan}

Teknolojik Etkenler

Günümüzde mobilyanın sembolleşmesinde önemli bir etken de teknoloji ve bilgi-iletişim alanındaki gelişmelerdir. Bilimsel gelişmeler paralelinde hızla ilerleyen teknoloji, mobilyada yeni içerikler ve biçimleme anlayışlarını da beraberinde getirmektedir. CAD/CAM teknolojileri, artan hesaplama ve üretim kabiliyetleri ile tasarım sürecinde fikir ile sonuç ürün arasında aracılık ederken tasarımcının fiziksel-

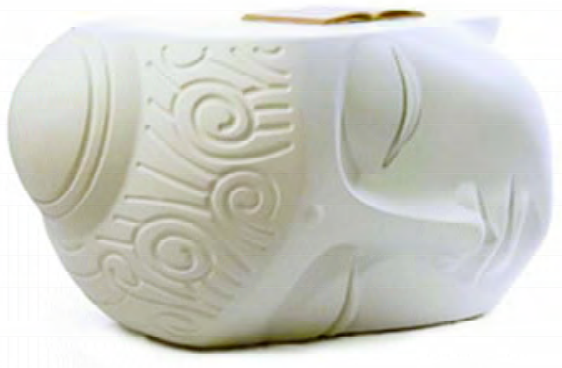

kavramsal yeteneklerini/kapasitesini arttırıp zenginleştirmekte ve daha özgür bir çalışma ortamı sağlamaktadır.

Detaylı formların üretimini mümkün kılan yöntemlerle mobilyada sembolik yaklaşımların arttığı görülmektedir. Hayvan formlarından yola çıkarak tasarladı̆̆ 1 'Animal Chair Collection' serisinde Maximo Riera, hipergerçekçi bir etki yaratmak için CNC teknolojisini kullanmıştır. El eskizleri bilgisayarda üç boyutlu modellere dönüştürülen Riera'nın heykelsi hayvan figürleri, CNC tezgahında sıkıştırılmış köpük bloklardan kesilmiş; kesilen farklı parçalar bir araya getirilmiş, yapıştırılmış, zımparalanmış ve boyanmıştır. Denge unsurunu sağlamak için kimi noktalarda iç strüktür elemanları kullanılmıştır (Resim 21).

Bilgisayar destekli tasarım alanında oluşan parametrik ve algoritmik tasarım gibi alt inceleme alanları mobilya biçimlerine yansımakta; tasarım süreçleri ve sonuç ürünler üzerinde önemli rol oynamaktadır. 'Tasarım sürecinde tasarımı etkileyecek verilerin parametreler (değişkenler) olarak belirlenmesi ve organizasyonu' olarak tanımlanan parametrik tasarımda, öncelikle hangi verinin diğeriyle nasıl ilişkili olduğu sayısal/geometrik olarak tanımlanmakta ve sinırlamaların

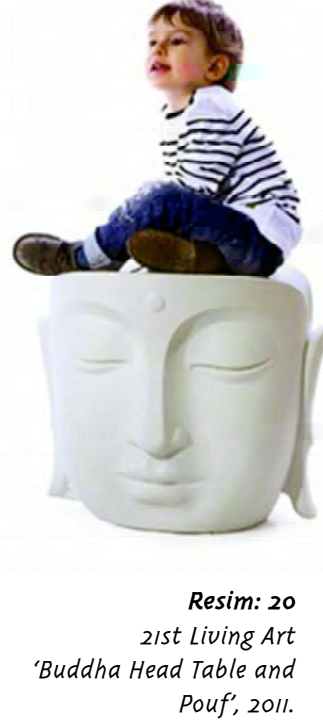

Pouf', 2011. 

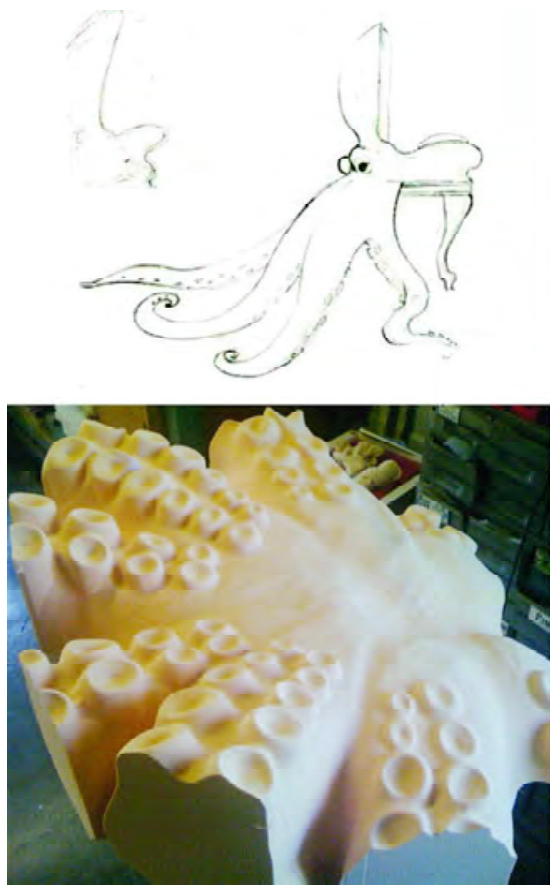

Resim: 21 belirtildiği bir tasarım stratejisi

Maximo Riera, 'Animal Chair Collection', 2011.
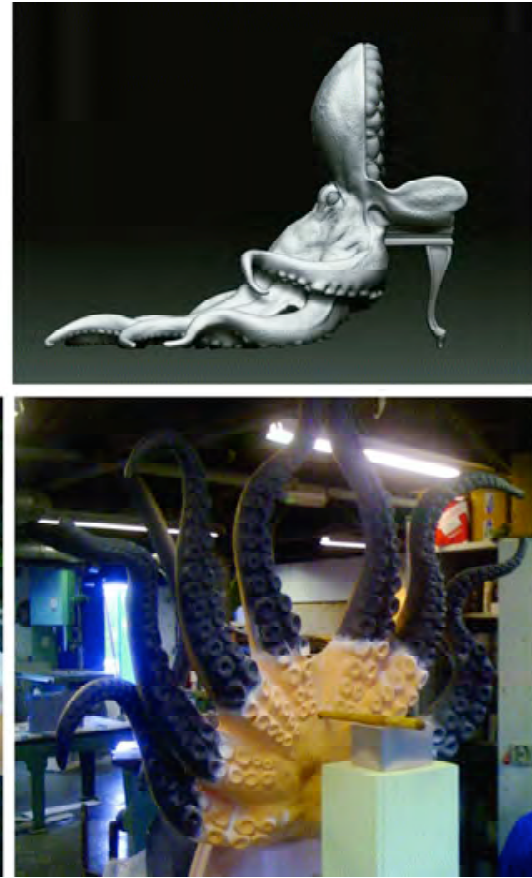

kurulmaktadır. Bu tür bir ilişki modeli bir

kez kurulduğunda parametre değerleri tasarımcı tarafından değiştirilerek diğer olası durumlar denenmekte ve türetilmektedir. Bunun bir örneği olan 'The Sectionimal', Şilili tasarım stüdyosu gt_2P tarafından parametrik tasarım yöntemiyle 'Section' isimli bilgisayar yazılımı kullanılarak üretilmiştir. $\mathrm{Bu}$ yazılım mobilyanın kesit sayısı, ölçü, biçim gibi parametrelerini kullanıcı gereksinimleri ve malzeme seçenekleri doğrultusunda adapte etmeye olanak vermektedir (Resim 22).

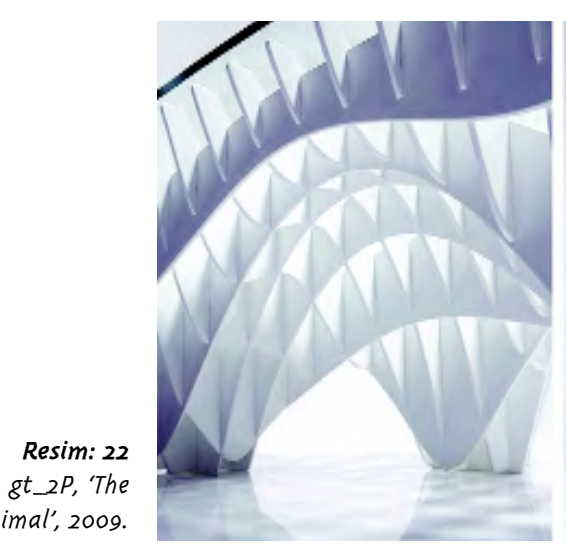

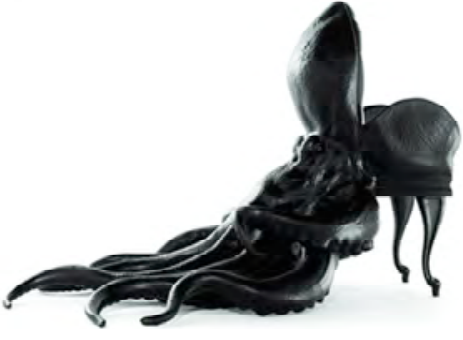

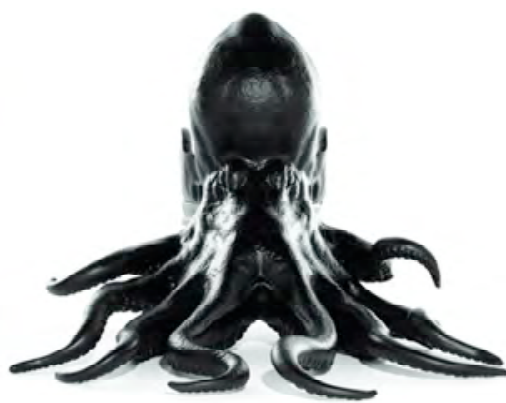

Günümüz yazılım programları sayesinde sonsuz tasarım çeşitliliği getiren dinamik form ve strüktürlerin sistematikleri artık sanal ortamda kurulabilmekte; bu çoklu sistemlerin bir araya gelişlerindeki düzen ve ritm mantığı çözümlenebilmektedir. Metafor olarak doğada yaşayan kuş sürülerinin kümeleşme biçimlerini kullanan 'The Starlings Table' için tasarımcı Joris Laarman ile çalışan Michal Piasecki, kuş sürülerinin hareket algoritmasından hareketle üç boyutlu bir bilgisayar simülasyonu hazırlamıştır. $\mathrm{Bu}$ yazılım sanal olarak uçan sürüyü herhangi
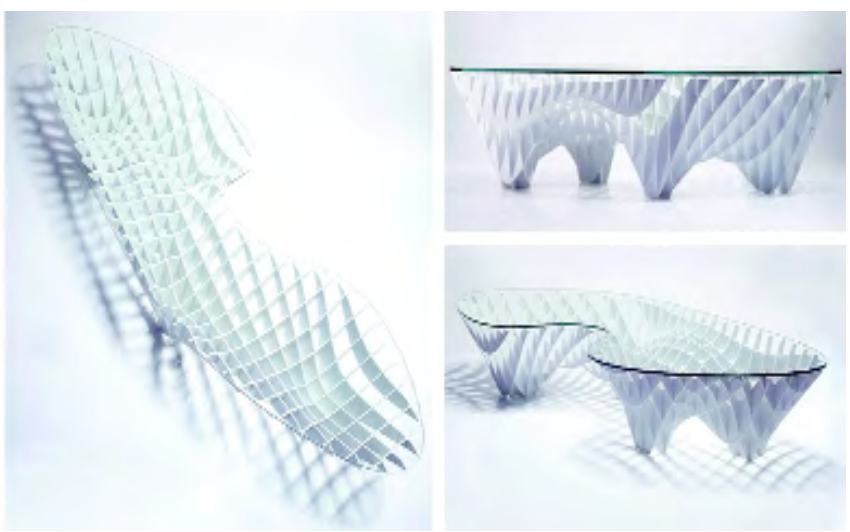


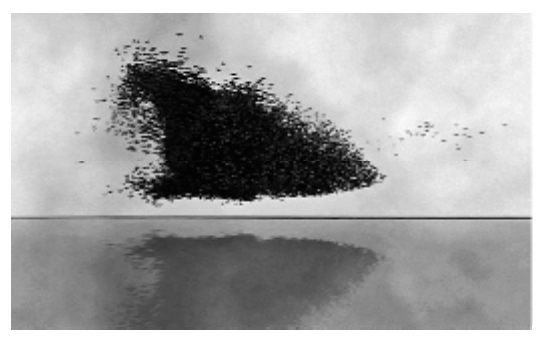

bir anda dondurabilmektedir. 'Stl dosyası' olarak dönüştürülen görüntüler, üç boyutlu yazıcı kullanılarak üretilmektedir. Materialise tarafından Stereolithography yöntemiyle meydana getirilen masa tasarımı son aşamada nikel ile kaplanmaktadır. İlerleyen teknoloji ile birlikte doğal ve organik formların tasarımcıların ilgisini giderek daha çok çektiği görülmektedir (Resim 23).

Gelişen teknoloji ile birlikte 'kişiye özel tasarım ve üretim' kavramları öne çıkmakta, Hızlı Prototipleme ve Stereolithography gibi üretim yöntemleri kullanıcının tasarım sürecine giderek daha çok dahil olmasını sağlamaktadır. Kişisel parametrelerle üretilen ilk mobilya örneklerinden olan 'Sinterchair'de kullanıcının favori müziği, sevdiği yazarı, filmi gibi tercihlerinden yola çıkılarak bir veri tabanı oluşturulmuş; bu bilgiler sandalyenin strüktürünü oluşturan değişkenler olarak bilgisayara yüklenmiş ve mobilya Selective Laser Sintering yöntemiyle üretilmiştir. Alman tasarım ekibi Vogt+Weizenegger, kullanıcı ile birebir ilişki içinde yürüyen ve bir gün içinde tamamlanan bu tasarım/üretim sürecini PLAN-A Fabrikası olarak adlandırmıştır. Bu proje, gelecekte mobilyanın kişisel imlerle sembolleşme noktasında ne yöne gidebileceğini gösteren ipuçları taşımaktadır (Resim 24). Standartlaşma yerine kişiselliğin ve kendini ifade etmenin tercih edildiği günümüzde, sayısal üretim teknolojileri ile

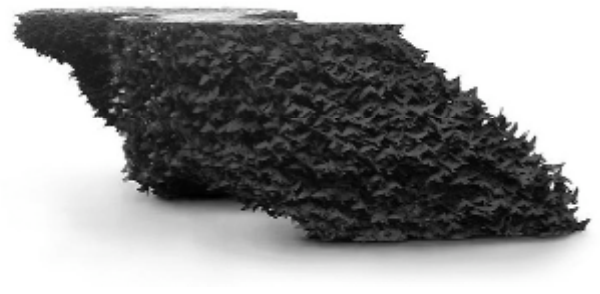

Resim: 23

Joris Laarman, 'The Starlings Table', 2010. mobilyada bireysel imlerin programlanması mümkün olmaktadır. $\mathrm{Bu}$ noktada, tasarımcının teknolojinin imkanlarına hakim olma düzeyi önem taşımaktadır. Pek çok tasarım alternatifine imkan veren sayısal üretim teknolojileri, tasarımcının elinde biçim kazanmaktadır. Hızlı Prototipleme ile objeler tek parçadan üretildiğinden, tasarımcının yapım süreci ile ilişkisi azalmakta; ancak bilgisayarla ilişkisi artmaktadır. İleride tasarımcının değil, kullanıcının final formunu verdiği,
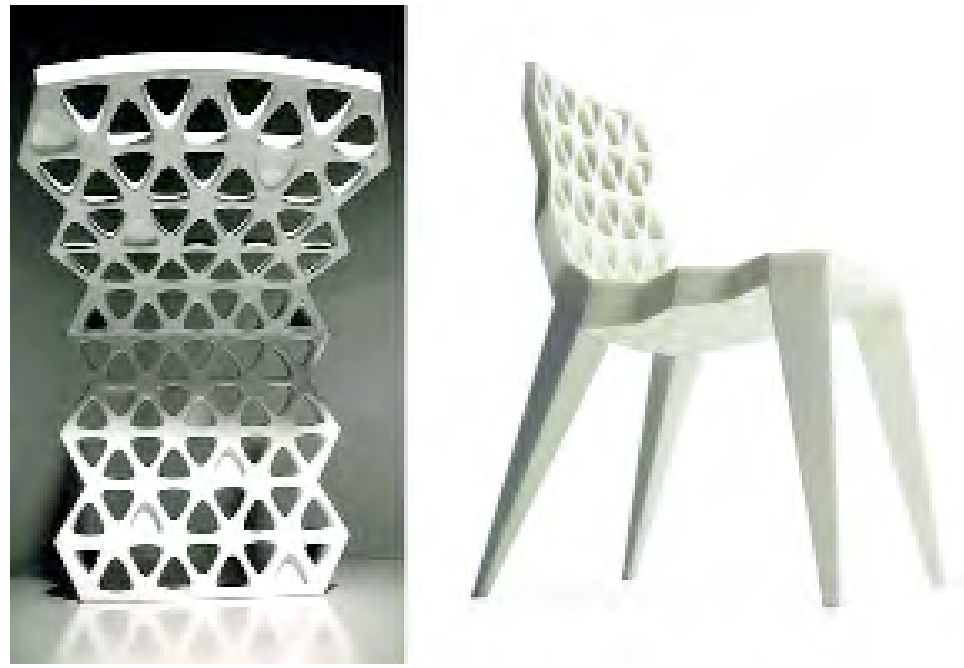

alternatifler arasından seçtiği mobilyaların artacağı düşünülmektedir. Tasarımcı ise kullanıcıya bu seçenekleri sunan kişi olacaktır.

Günümüzde sayısal teknolojilerin mobilya biçimleri üzerindeki bir etkisi de bilgisayarda kullanılan çizim programlarıyla hayatımıza giren formlardır. Bugün çoğu tasarımcı mobilyalarını iki ve üç boyutlu 


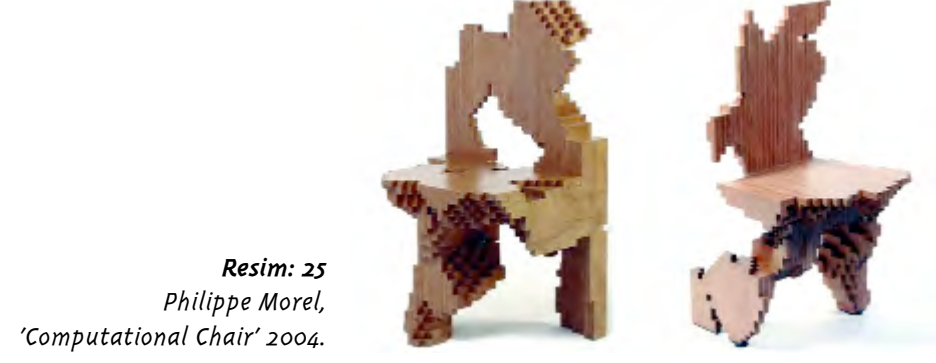

programlarda modellemekte; bu ise onların sembol arama sürecinde sanal ortamın sunduğu biçimlerden etkilenmesine yol açmaktadır. Farklı çizgi-yüzey göstermeleri (wireframe, piksel, grid sistem) ve komutlar (lathe, extrude, boolean) bilgisayar biçim dilinde tasarımcıya esin kaynağ olan öğelerden bazılarıdır. Pikselize edilmiş bir forma sahip 'Computational Chair', bilgisayar algoritmalarıyla oluşturulan biçim alternatifleri içinden yirmi beş tanesinin seçilmesi ve lamine ahşap malzemeyle üretilmesi sonucunda meydana getirilmiştir (Resim 25).

Sayısal üretim teknolojileri, giderek artan tasarım ve üretim kapasiteleriyle tasarım sürecinde düşünce ile ürün arasında aracılık ederken, kullanıcının bedenselzihinsel sınırlarını genişletebilmesine katkıda bulunmakta, tasarımcının fiziksel/kavramsal yeteneklerini ve kapasitesini arttırıp zenginleştirmekte, mobilya tasarım süreçlerine yeni yöntem, form ve strüktür biçimleri katmakta, tasarımcıya daha serbest bir çalışma ortamı sağlamakta ve fikirlerini geliştirme şansı vermektedir.

Resim: 26 Peter Donders, 'C-Bench', 2010.
Teknolojik gelişmelerin bir diğer sonucu ise yeni özgürlükler sunan kompozit
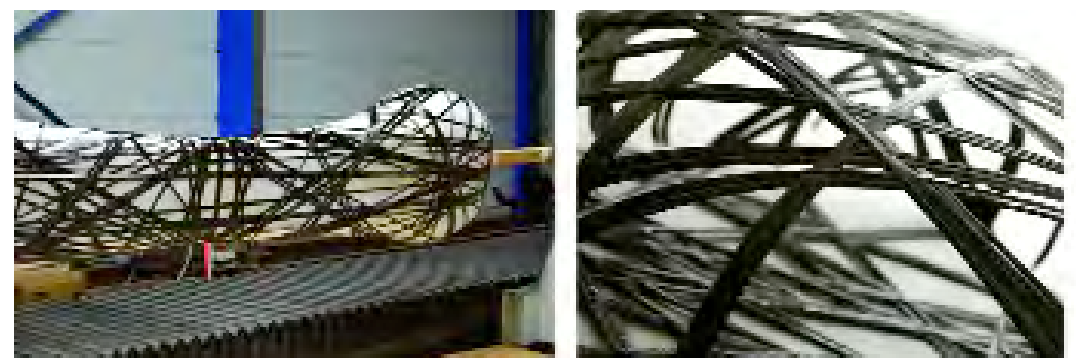

malzemelerdir. Malzeme dayanımlarının arttırılmasıyla görsel ezberler bozulmakta; bugüne değin alış1lagelmiş biçim ve strüktür mantığının ötesine geçen tasarımlar yapılmaktadır. Hafif ancak sağlam malzemelerin beklenilenden ağır yükleri taşımasıyla incelen mobilya kesitleri, görselliğe katkı sağlamaktadır. Formun olanakları arttıkça tasarıma konulacak sınırlar ve tanımlar da genişlemektedir. Buna bağlı olarak tasarımlar, sembol ve metafor gibi iletişim imleriyle daha kolay ilişkilendirilebilmektedir. Yapısı çelikten dört kat daha hafif ama üç kat daha dayanıklı bir malzeme olan karbon fiberle üretilen mobilyalar bu anlamda dikkat çekicidir. 'C-Bench' isimli tasarımında Peter Donders, şerit karbon fiberi sonradan çıkardı ğ etrafında döndürerek çizgisel biçim dili güçlü bir oturma elemanı meydana getirmiştir (Resim 26).

Kolay biçim alan malzemeler, sayısal teknolojilerin de etkisiyle tasarımda organik ve kompleks formlara yönelimin artmasına neden olmaktadır. İrrasyonel çizgide bir tasarım olan 'Aqua Table' ile Zaha Hadid, suyun damlamasını andıran bir forma gönderme yapmıştır. Taşıyıcı strüktürü lamine poliüretan reçineden olan masanın yüzeyi, kaymaz şeffaf silikon jel ile kaplıdır. Süreklilik gösteren yapıda bir panel duvar sistemi olan Luca Nichetto tasarımı 'Neverending Evolution' ise Corian malzeme kullanılarak üretilmiştir. Devamlılık gösteren yüzeyleri ve asimetrik yapıları ile bu tasarımlar, 'hareket' ve 'akış' gibi kavramları vurgulamaktadır (Resim 27).

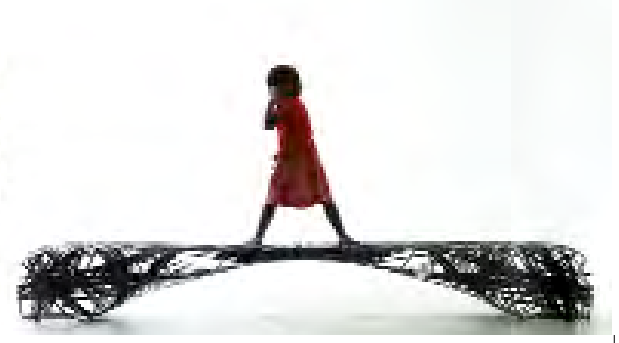




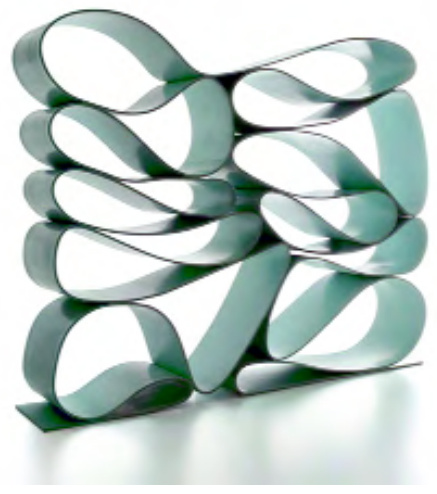

Resim 27

Günümüzde malzeme, nanoteknolojinin sağladı̆̆ı imkanlar sayesinde kullanıcı ile etkileşime girebilir, çevre koşullarını değerlendirebilir; bunu görselliği ve eylemiyle ortaya koyarak dişa yansıtabilir hale gelmiştir. 'Akıllı malzeme' olarak adlandırılan bu bileşenler 1şık, sıcaklık, basınç, magnetik alan ya da kimyasal bir etki sonucu görüntü, şekil ya da boyut değiştirebilmekte; bu değişimler sonucunda farklı görsel dinamikler oluşturabilmektedir. Malzemenin aktif olma durumu, tasarım endüstrisine sürekli değişen özellikler kazandırmaktadır.

Mobilyalar geliştirilen güncel tasarım yöntemleriyle zengin biçim olanağına kavuşurken, malzeme kendi karakteristik özellikleriyle tasarım süreçlerinde etkin roller oynamaktadır. Termokromik kaplaması sayesinde kullanıcı ile etkileşime giren 'Hotseat', 1S1 değişimlerini hafızaya alarak yüzeyi üzerinde görselleştiren bir masa ve bank tasarımıdır (Resim 28).

Farklı çeşitleriyle birçok işlevi yerine getiren akıllı malzemeler, mobilya tasarımında ürünün çevreye uyum sağlayabilme; oluşan veya oluşabilecek çevresel etkilere karşı kendini yeniden yapılandırabilme potansiyelleri ile görevlendirilmektedir. Yakın gelecekte

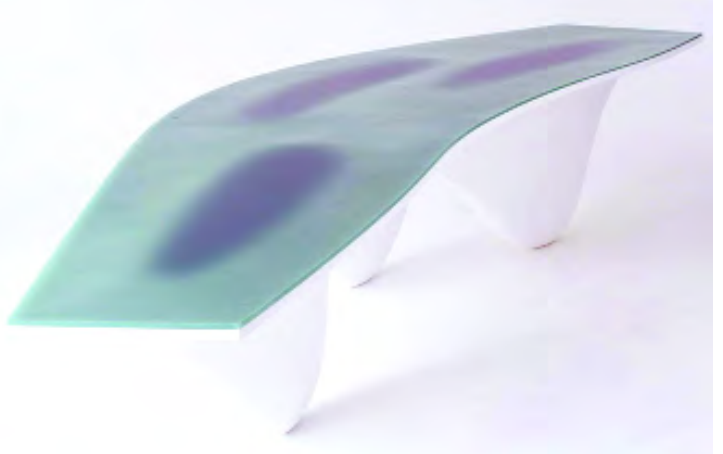

Resim: 27

Luca Nichetto, 'Neverending Evolution' 2009 ve Zaha Hadid, 'Aqua Table', 2006. Resim: 28

Jay Watson, 'Hotseat', 2011. teknoloji ile ilişki içindeki mobilyalar değişim isteğine daha çok yanıt verebilecektir. Mobilya; strüktürel yapıdan oluşum geometrilerine, teknik edinimlerden nanoteknolojik olanakların tasarıma getireceği yeniliklere kadar insan-çevre etkileşiminin bir aracı olacaktır.

Medya ve bilişim teknolojilerinin yaşam içinde kapladı̆̆ı alanın genişlemesi sonucu bireysel paylaşımlar artmış, kültürler arası etkileşim hızlanmıştır. İletişim ortamındaki bu değişim tasarımc1-
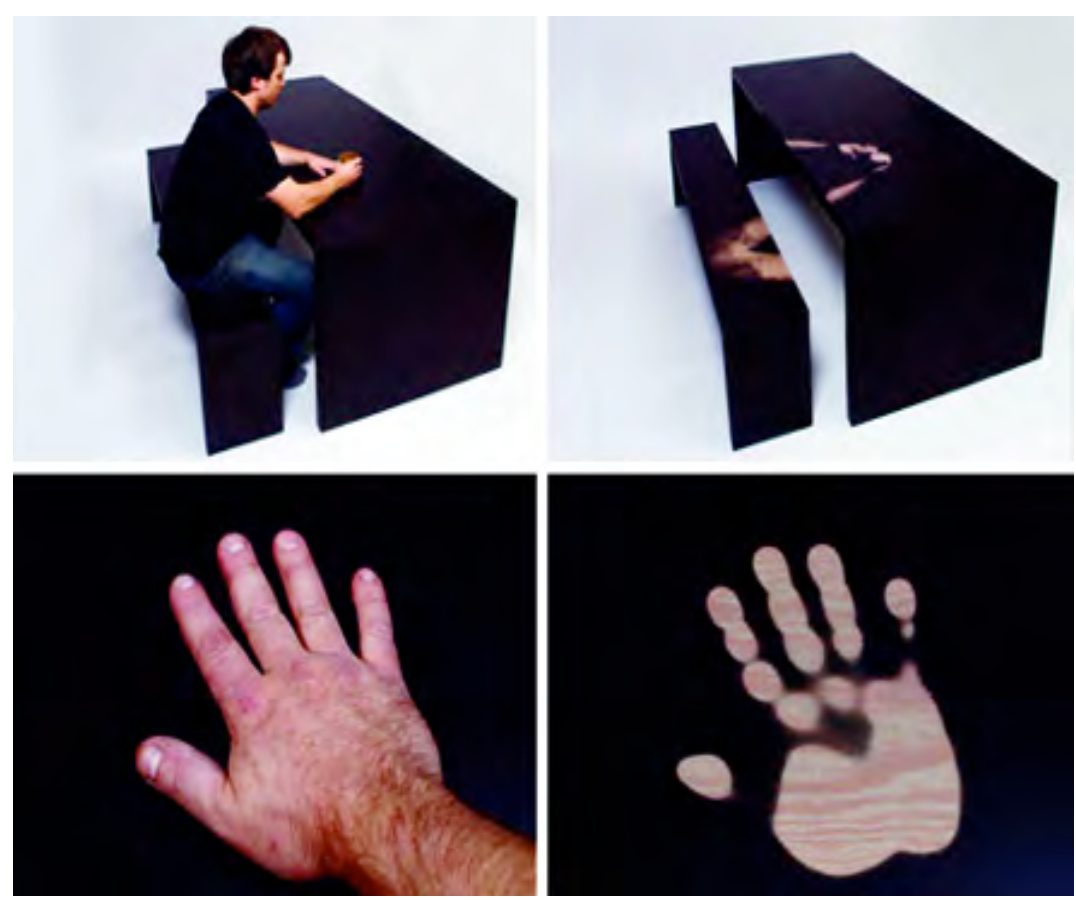
kullanıcı ilişkisini de etkilemiş, tasarımcılar tasarımlarını sosyal platformlara taşıyarak daha fazla kullanıcıyla buluşmayı hedefler hale gelmişlerdir. Toplumun büyük çoğunluğunun dahil olduğu ve 'sanal ortam' olarak tanımlanan platformda öne çıkabilmek adına geliştirilen stratejilerin geçerlilik süreleri giderek kısalmakta ve bu durum yeni olana yönelimi zorunlu kılmaktadır (Schifferstein ve Hekkert 2008, 333). Sürekli değişim halinde olan bu ortam, tasarımcıları ifade gücü yüksek tasarımlar yapmaya yönlendirmektedir.

Gelişen bilişim teknolojileri ile bilginin hızlı iletimi sayesinde küresel sınırlar kalkmış; tasarımcının ve tasarımın evrenselleşmesinin zemini oluşmuştur. İlerleyen teknoloji, mobilyada yeni form üretimi ve yeni kullanım biçimlerinin gelişmesinde belirleyici rol oynayacak; mobilya-sembol ilişkisini değiştirmeye devam edecektir.

\section{Sonuç}

İletişim çağı olarak tanımlanan günümüzde mobilyanın, pratik/işlevsel kullanım bağlamından çıkarak; istek, düşünce ve kimlik bildiren, kültürel sembollerle yüklü bir nesneye dönüştüğü görülmektedir. Taşıdığı estetik ve sembolik imlerle tasarımı kullanan/izleyen kişilerin bilgi ve kültürel birikimine bağlı olarak devreye giren pek çok mesajı da aktaran mobilyada iletişim, biçim dili ile iletilen gösterge, sembol ve metaforlar yoluyla sağlanmaktadır. Sanatçı ve tasarımcılar estetik bakış açılarını yansıtmak için ve/veya felsefi bir söylemde bulunmak için mobilya formunu kullanabilmekte; bu yolla mobilyayı sembolleştirebilmekte; tasarımları -pratik kullanım değeri olsun ya da olmasındüşünsel kurgu ileten çağdaş sanat nesneleri olarak programlayabilmektedir. Sembolleşen mobilyalara günümüzde giderek daha sık rastlanmakta; yaşam koşullarının ise bu durumu desteklediği görülmektedir. Mobilyaların sembolleşmesi sosyo-kültürel ve teknolojik boyutta irdelendiğinde -gerek estetik, gerekse felsefi boyutta- yaygın kullanıma ulaşmasındaki etkenler de netleşmektedir. Farklı olmanın ve farklı olana yönelmenin bir ihtiyaca dönüştüğü günümüzde her sektörde tasarımcılar yeniyi yaratmaya odaklanırken, kullanıcılar da özgün olanı aramaya başlamışlardır. Bu durum mobilya üretimine de yansımış, değişik biçime ulaşma çabaları sembolik mobilyaların yaygınlaşmasında etkili olmuştur. Sosyokültürel boyutta etkileşim tasarımcının sembol oluşturması, kullanıcının sembol nesne kullanması ve bu nesnelerin güncel yönelimlerle ilişkilendirilmesi noktasında olmaktadır.

Teknoloji ve bilgi-iletişim alanındaki gelişmeler geçmişte yapılması mümkün olmayan mobilyaların üretimini olanaklı kılarak form ve strüktür yapılarını değiştirmektedir. Semboller yüzeysel süsleme boyutundan uzaklaşmakta; mobilya biçimi, malzemesi, boyutu ve dokusuyla tümüyle bir sembole dönüşmektedir.

Görülmektedir ki; mobilyada iletişim işlevi yakın gelecekte daha da önem kazanarak tasarımda yer alacak, sembolleşme süreci teknolojik gelişmelere paralel olarak biçimlenmeye devam edecektir. Bunun yanında, bireyselliğe olan vurgunun öne çıkacağı, mobilyanın tasarımcısı ve kullanıcısı ile daha yakın ilişki içine gireceği düşünülmektedir. Mobilya tasarımındaki ve üretimindeki sınırlamalar ortadan kalktıkça kullanıcı Sayı 16, $2013 \mid 101$ 
deneyimlerinin de önemi artacaktır. Endüstriyel yöntemlerle seri olarak üretilmiş ürünlere karşılık olarak tasarımcıların, kendi imzalarını taşıyan 'özelleşmiş’ ürünlerle daha çok karşımıza çıkacağ 1 ve kişisel ifadelerin güçleneceğ $i$ öngörülmektedir. Tasarımcılar, mobilyanın biçim dilini yeniden yorumlayarak bildirilerini aktarmaya; güncel malzeme ve üretim teknolojilerini keşfetmeye yönelik çalışmalar yapmaya, deneysel tasarım ve üretim biçimleri geliştirerek kendilerini ifade etmenin farklı yollarını aramaya devam edeceklerdir. Sembolik mobilya tasarımlarına olan ilginin giderek arttığ göz önüne alındığında; tasarımcılar için öncelikli çıkış noktası "bireysel kimlikleri ifade edebilme özelliğine sahip özgün programlar oluşturmak" olmalıdır
KAYNAKÇA

Arad, Ron. 2013. Alldesign Uluslararast 2. Tasarım Konferansları, Hilton İstanbul Convention \& Exhibition Center

Bayrakçı, Oğuz. 2004. Căğdaş Illetişsim Kuramları Açısından Tasarımda Illetişimsel Modeller, MSGSÜ Mimarlık Fakültesi Yayınları, İstanbul.

Bilgin, Nuri. 1983. Çeşitli Sosyo-Kültürel Gruplarda Eşya Sistemleri ve İnsan-Eşya İliškileri, Doçentlik Tezi, Ege Üniversitesi Edebiyat Fakültesi Yayınları, No:28, İzmir.

Buchler, Justus. 1955. Philosophical Writings of Peirce, Dover Publications, Inc., NY.

Lovell, Sophie. 2009. Limited Edition, Prototypes, One-Offs and Design Art Furniture, Birkhauser Verlag AG, Basel.

Mugge, Ruth; Schifferstein, Hendrik.N.J.; Schoormans, Jan,P.L. 2008. Product Attachment and Satisfaction: The Effects Of Pleasure and Memories, European Advances in Consumer Research (8): 325-331.

Özsoy, H.Özkal. 2009. Endüstri Ürünleri Tasarımında Eğretilemeli Anlatımların Yöntemsel Kullanımı, Doktora Tezi, MSGSÜ Fen Bilimleri Enstitüsü, Ístanbul.

Schifferstein, Hendrik.N.J.; Hekkert, Paul. 2008. Product Experience, Elsevier Ltd., USA.

Uzunarslan, H. Sebnem. 2010. Aesthetic Content in Experimental Design, The Eighteenth International Congress of Aesthetics: Diversities in Aesthetics, Beijing, China. Zapçı, Nurhan. 1996. Alıșkanlıkların Konut Araçları Tasarımına Etkisi Üzerine Bir Araştırma, Yüksek Lisans Tezi, MSGSÜ Fen Bilimleri Enstitüsü, İstanbul. 